\title{
Editorial
}

Journal of Innate

Immunity
J Innate Immun 2016;8:1-2

DOI: $10.1159 / 000443137$

\section{Nobel Parasites in the Kingdom of Invertebrates}

The 2015 Nobel Prize in Physiology or Medicine was awarded to Youyou Tu, William C. Campbell, and Satoshi Ōmura for 'their discoveries concerning a novel therapy against malaria and infections caused by roundworm parasites'. While Youyou Tu received the prize for her ground-breaking research in traditional Chinese medicine and the discovery of artemisinin, an antimalarial drug, William C. Campbell and Satoshi Ōmura have focused their research on parasitology and chemotherapy of parasitic infections and the discovery of novel drug candidates from unknown microorganisms, respectively.

According to the World Health Organization (WHO), approximately 3.2 billion people are at risk of malaria and 214 million malaria cases were estimated in 2015 with a mortality rate exceeding 430,000 [1]. These numbers emphasize how urgent it is to develop novel antimalarial therapies. Malaria is a mosquito-borne disease where the Plasmodium parasite employs the female Anopheles gambiae mosquito as a vector (for a review see [2]). Considering the global disease burden associated with malaria, it is no surprise that it has attracted the attention of many researchers. Notably, malaria and innate immunity are tightly interwoven and thus the Journal of Innate Immunity has also published a number of articles within the last years that deal with virulence mechanisms employed by this pathogen [3-5].
Apart from Plasmodium, other parasites, such as protozoa and nematodes (roundworms), also play a significant role in innate immunity. However, parasite immunology is an otherwise still neglected area of research, and other organisms are currently subject to much more interest, in particular Drosophila since it provides a good model to study immune responses in invertebrates [6-9]. The 2015 Nobel Prize will therefore hopefully raise awareness of parasite immunology in the coming years. This is of great importance since, in addition to malaria, parasites are the causative agents of many other diseases, such as Leishmania species which trigger severe cutaneous disease in South America. In order to develop novel strategies against Leishmania infection, a better understanding of host-parasite interactions is required; therefore, studies dealing with the role of neutrophils during disease progression will help to better understand mechanisms employed by this pathogen [10]. Another important parasite is Toxoplasma gondii, which can infect all mammals - it is estimated that more than one third of the world population has been in contact with this pathogen. The Journal of Innate Immunity recently published that T. gondii triggers inflammatory reactions via Toll-like receptors [11], which is another example that demonstrates the important interaction between parasites and the innate immune system.

\section{KARGER}

E-Mail karger@karger.com

www.karger.com/jin
(C) 2016 S. Karger AG, Basel

$1662-811 X / 16 / 0081-0001 \$ 39.50 / 0$ 
Parasites belong to the smallest eukaryotic organisms and are therefore not only important pathogens, but can also serve as an ideal object for different disease models. Wound healing is such an example and recent work has shown that nematode models are fast and reliable tools that can be used to study, for instance, the role of complement and extracellular matrix proteins in response to in- fection [12]. Taken together, we hope that the 2015 Nobel Prize in Physiology or Medicine will boost an increased interest in the field of parasite immunology in the years to come.

Heiko Herwald, Lund Arne Egesten, Lund

\section{References}

1 WHO: 10 facts on malaria. http://www.who. int/features/factfiles/malaria/en/.

2 Clayton AM, Dong Y, Dimopoulos G: The anopheles innate immune system in the defense against malaria infection. J Innate Immun 2014;6:169-181.

-3 Upton LM, Povelones M, Christophides GK: Anopheles gambiae blood feeding initiates an anticipatory defense response to Plasmodium berghei. J Innate Immun 2015;7:74-86.

4 Yassine $\mathrm{H}$, Kamareddine L, Chamat S, Christophides GK, Osta MA: A serine protease homolog negatively regulates TEP1 consumption in systemic infections of the malaria vector Anopheles gambiae. J Innate Immun 2014; 6:806-818.
5 Ramirez JL, Garver LS, Brayner FA, Alves LC, Rodrigues J, Molina-Cruz A, Barillas-Mury C: The role of hemocytes in Anopheles gambiae antiplasmodial immunity. J Innate Immun 2014;6:119-128.

6 Herwald H, Egesten A: Chasing flies because time flies. J Innate Immun 2015;7:1-2.

7 Cantera R, Barrio R: Do the genes of the innate immune response contribute to neuroprotection in Drosophila? J Innate Immun 2015;7:3-10.

-8 Taillebourg E, Schneider DS, Fauvarque MO: The Drosophila deubiquitinating enzyme dUSP36 acts in the hemocytes for tolerance to listeria monocytogenes infections. J Innate Immun 2014;6:632-638.

-9 Vitak N, Johnson KN, Sester DP, Stacey KJ: A novel pathway of cell death in response to cytosolic DNA in Drosophila cells. J Innate Immun 2015;7:212-222.
10 Carlsen ED, Jie Z, Liang Y, Henard CA, Hay C, Sun J, de Matos Guedes H, Soong L: Interactions between neutrophils and Leishmania braziliensis amastigotes facilitate cell activation and parasite clearance. J Innate Immun 2015;7:354-363.

11 Salazar Gonzalez RM, Shehata H, O'Connell MJ, Yang Y, Moreno-Fernandez ME, Chougnet CA, Aliberti J: Toxoplasma gondii-derived profilin triggers human Toll-like receptor 5 -dependent cytokine production. J Innate Immun 2014;6:685-694.

12 Arefin B, Kucerova L, Dobes P, Markus R, Strnad H, Wang Z, Hyrsl P, Zurovec M, Theopold U: Genome-wide transcriptional analysis of Drosophila larvae infected by entomopathogenic nematodes shows involvement of complement, recognition and extracellular matrix proteins. J Innate Immun 2014;6:192204 